\title{
PANDANGAN RASUL PAULUS \\ TENTANG JEMBATAN PENGANTAR INJIL. \\ KAJIAN MISIOLOGI TERHADAP 1 KORINTUS 9:1-23
}

Ditulis oleh : Seri Damarwanti, SE, M.Th ${ }^{1}$

\begin{abstract}
The missionary task is the responsibility, given by the Lord Jesus Christ, to all Christians. The underlying of this idea are taken from 1 Corinthians 9: 1-23. The Apostle Paul gives several principles and approaches regarding bridges that can be used by Christians to carrying out missionary tasks for everyone. Everyone is a priority to the Gospel and every community has a bridge to the Gospel.

Keywords: task, mission, christian, bridge, Gospel, community, people
\end{abstract}

\begin{abstract}
Abstrak
Tugas bermisi merupakan tanggungjawab yang diembankan oleh Tuhan Yesus Kristus kepada seluruh orang Kristen. Pemikiran yang mendasari ide ini diambil dari 1 Korintus 9:1-23. Rasul Paulus memberikan beberapa prinsip dan pendekatan mengenai jembatan yang dapat dipakai oleh orang Kristen dalam melakukan tugas misi kepada setiap orang. Setiap orang merupakan prioritas kepada Injil dan setiap komunitas memiliki jembatan kepada Injil.

Kata Kunci: tugas, misi, Kristen, jembatan, Injil, kelompok, orang
\end{abstract}

\section{Latar Belakang Penulisan}

Di dalam media massa dan media sosial Indonesia akhir-akhir ini, begitu besar dan banyak issue yang berkembang mengenai eksplotasi perbedaan nilai-nilai kepercayaan umat beragama. Hal itu tidak menjadi masalah apabila setiap agama dan kepercayaan yang berbedabeda itu berjalan saling berdampingan dalam kebersamaan, namun yang terjadi adalah sebaliknya. Issue sentral dari pembahasan mengenai perbedaan prinsip itu ada karena setiap pihak cenderung mencari pembenaran bagi kelompoknya sendiri, disamping itu juga melakukan

\footnotetext{
${ }^{1}$ Penulis adalah Dosen di STT Nazarene Indonesia.
} 
intimidasi kepada kelompok agama lain, baik itu secara langsung atau tidak langsung, disadari atau tidak disadari.

Akibat paling buruk dari pembiaran terhadap kondisi ini adalah ancaman akan diintegrasi bangsa yang mengancam kesatuan kehidupan berbangsa dan bernegara di Indonesia. Bagi orang Kristen, tidaklah bijaksana apabila mengikuti arus untuk juga menuliskan dan melakukan aksiaksi yang memperbesar jurang perbedaan antar kelompok. Mengingat panggilan bagi setiap pengikut Kristus untuk menjadi SAKSI KRISTUS, dan menjadi PEMBAWA DAMAI dan menjadi media REKONSILIASI antara Allah dan manusia.Akan lebih bijaksana dan benar di mata Allah dan manusia bila orang Kristen dapat memberikan pengaruh yang baik di dalam komunitasnya.

Salah satu hal yang menjadi fokus pada KESAKSIAN orang Kristen adalah menolong orang yang belum percaya Yesus menjadi mengenal DIA dan mempercayaiNYA. Untuk dapat menjadi saksi Kristus yang efektif, orang percaya perlu mengenal dan belajar beberapa prinsipprinsip yang dapat dipakai untuk melakukan pendekatan kepada orang atau kelompok non Kristen. Ada banyak teori dan pendekatan yang dapat dipakai dalam Misiologi, namun dalam paper ini penulis akan melihat pada prinsip-prinsip pendekatan yang dipakai Rasul Paulus untuk menjangkau orang non Kristen pada beberapa golongan/kelompok, berdasarkan 1 Korintus 9 :123.

\section{Dasar Biblika Misi Allah Bagi Dunia}

Ayat-ayat yang kental dengan nilai-nilai Misiologi dan menjadi dasar teologis dalam praktik "bermisi" setiap orang Kristen, terdapat banyak sekali dalam Alkitab. Beberapa diantaranya adalah : 
Matius 28:16-20

“ Karena itu PERGILAH, JADIKANLAH semua bangsa muridku dan BAPTISLAH ..., AJARLAH... Ketahuilah bahwa Aku MENYERTAI kamu senantiasa sampai kepada AKHIR ZAMAN"

Bagian ini mengandung sebuah PERINTAH untuk melakukan aksi penjangkauan jiwa. Sekaligus mengandung JANJI sebagai sebuah jaminan dari Allah yang empunya tuaian dan pekerjaan itu, bahwa IA akan memperlengkapi dan MENYERTAI orang-orang yang diutus memberitakan Injil Kerajaan Surga. Maka dari itu, nats ini bukanlah sesuatu yang bersifat pilihan, yang dapat dikerjakan atau ditinggalkan, namun merupakan sebuah ORDER DAN AMANAH untuk dikerjakan dengan sungguh-sungguh dan penuh tanggungjawab oleh setiap orang Kristen.

\section{Korintus 9:1-23}

Bagian Firman Tuhan ini, yang akan digali kemudian, secara gamblang menunjukkan bahwa panggilan untuk memberitakan Injil bukanlah sebuah tugas yang eksklusif dan berlaku bagi orang-orang tertentu saja seperti Rasul Paulus dan para misionari. Tugas memberitakan Injil adalah sebuah aksi yang tidak dapat ditawar lagi bagi setiap orang Kristen, karena seperti Rasul Paulus berkata : "agar aku mendapat bagian dalam Injil”, adalah sebuah tujuan bersama yang ingin dicapai seluruh orang Kristen, bukan hanya orang-orang tertentu saja.

Bukan hanya mereka yang terpanggil secara khusus untuk menjadi misi dan penginjil dallam profesinya, namun juga oleh kaum awam yang berkecimpung dalam dunia sekuler dan profesional kerja. Siapapun mereka, apapun profesinya, dan bagaimanapun keadaan yang menyertainya. 


\section{Profil Rasul Paulus}

Pemikir terbesar dalam Perjanjian Baru yang menafsirkan makna pribadi dan pekerjaan Yesus adalah seorang Farisi yang telah bertobat, yaitu Paulus. Bila seorang sejarawan ingin memahami pemikiran Paulus, maka ia perlu menganalisa pengaruh-pengaruh yang membentuk pemikiran Paulus dalam konteks historisnya. Tugas historis ini sangat sulit dilaksanakan karena Paulus itu adalah manusia dari 3 (tiga) dunia, yakni Yahudi, Yunani dan Kristen.Walaupun ia dilahirkan di Tarsus, sebuah kota Yunani di daerah Kilikia, namun ia dibesarkan di dalam keluaga Yahudi yang taat kepada adat istiadat Yahudi yang keras (Filipi 3:5) dan ia juga sangat membanggakan warisan Yahudinya (Roma 9:3; 11:1). Ia mengakui pernah hidup sebagai seorang Yahudi yang sangat patuh pada tradisi lisan kaum Farisimelebihi rekan-rekannya yang lain.

Paulus juga mengenal dunia Yunani, dan pernah terjun dalam melaksanakan misi pengembangan gereja di kawasan Yunani Romawi. Dalam menafsirkan Injilpun ia mengikuti pola yang mirip kultur Yunani. Karena ia menghabiskan masa kanak-kanaknya di Tarsus, maka ia pasti pernah menyaksikan ahli filsafat Stoa yang sisnis, yang senang berkeliling dan biasanya berdiri dan berpidato di sudut-sudut jalan di Tarsus ... Paulus menguasai Bahasa Yunani, dan metafora-metafora sastra yang digunakannya lebih mencerminkan kehidupan kota daripada latar belakang pedesaan. . . gayanya mirip dengan cara berkata-kata kaum Stoa.

Pertobatannya menguras habis ide-ide keagamaan yang lama, kemudian menggantikannya dengan susunan ajaran teologi yang lengkap dan siap pakai. Pengalamanpengalaman semasa kanak-kanak dan remajanya telah berperan mempersiapkannya untuk 
memenuhi tugas yang telah ditetapkan Allah baginya. Itulah sebabnya kita harus menginterpretasikan ide-ide Paulus berdasarkan keanekaragaman latar belakangnya. ${ }^{2}$

Teologi Paulus memberi perhatian khusus pada manusia baru dalam Kristus. Penjelasannya mengenai anugerah Allah melibatkan perubahan dalam etika pribadi, karena manusia baru itu mutlak harus mengembangkan tata nilai baru mereka. Ajaran etis Paulus adalah bagian mendasar dari seluruh sistim teologinya. ${ }^{3}$

\section{Tentang 1 Korintus 9:1-23}

Skema Strategi Misi Yang Dilakukan Rasul Paulus Berdasarkan 1 Korintus 9:1-23

\footnotetext{
${ }^{2}$ George Eldon Ladd, Teologi Perjanjian Baru 2, (Kalam Hidup: Bandung), 1999, hal 81-82.
}

${ }^{3}$ Donald Guthrie, Teologi Perjanjian Baru 3, (Jakarta: BPK GunungMulia), 1993, hal 271-272. 


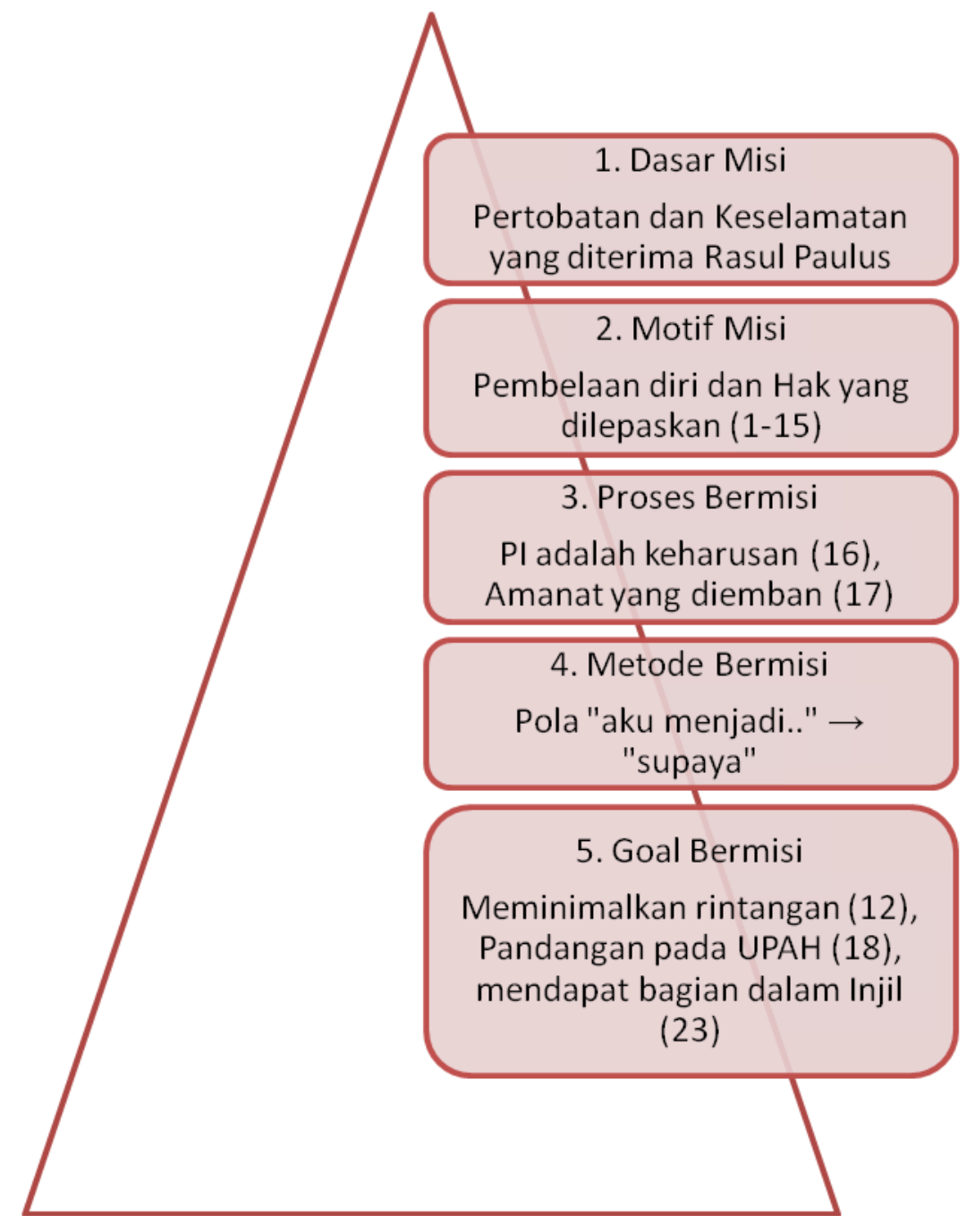

Gambar 1.1

Kerangka Konseptual Misi Dalam 1 Korintus 9:1-23

Prinsip Umum Dalam Konteks 1 Korintus 9:1-23

Surat 1 Korintus 9:1-23 berbicara mengenai beberapa hal yang berhubungan dengan pelayanan penggembalaan Rasul Paulus kepada jemaat Korintus. Bila dibagi dalam sebuah bagan atau alur berpikir, 1 Korintus 9:1-23 ini dapat dibagi menjadi beberapa pokok pikiran yang menolong pembaca mengerti dasar pemikiran dan tulisan Rasul Paulus, yaitu : 


\section{Dasar Misi}

Walaupun tidak dituliskan dalam perikop ini, namun dapat dimengerti bahwa bagian ini ditulis untuk menjelaskan Hak Jawab Rasul Paulus terhadap pihak-pihak yang menentang legalitas kerasulannya. Merunut dari bagian-bagian sebelumnya di pasal 3 yang berbicara mengenai Dasar Iman, dilanjutkan dengan Otoritas Allah sabagai Hakim Agung dan sikap dalam jemaat yang berhubungan dengan etika berjemaat, kerendahan hati dan sikap terhadap dosa pasal ke 4 sampai 7, dan mengerucut pada pandangan mengenai pandangan Iman Kristen tentang makanan yang dipersembahkan untuk berhala di pasal 8 dan pada akhirnya penjelasan Rasul Paulus mengenai hak dan kewajibannya sebagai Rasul.

\section{Semua bagian terdahulu itu ada dan ditulis bertolak pada pertobatan Rasul Paulus}

dan panggilannya menjadi Pemberita Injil Kristus. Jelaslah bahwa dasar aksi yang dilakukan Rasul Paulus dalam menjangkau banyak orang non Yahudi bagi Kristus adalah panggilannya untuk menjadi Pemberita Injil dan menjangkau sebanyak mungkin orang untuk diselamatkan, yang mana hal ini berhubungan erat dengan pertobatan dan penahlukkan dirinya pada Kristus.

\section{Motif dan Proses Misi}

Dalam bagian pertama perikop ini (ayat 1-15), dituliskan mengenai Hak dan Kewajiban yang seharusnya didapat dan dilakukan Rasul Paulus. Bagian ini penuh dengan argumentasi yang seolah-olah merupakan pembelaan diri Rasul Paulus terhadap legalitas kerasulannya yang dipermasalahkan banyak orang, termasuk rekan Rasul Yesus Kristus yang lain dalam pekerjaan pemberitaan Injil. Beberapa pokok pikiran penting yang dapat ditangkap dalam "pembelaan diri" ini antara lain adalah : 
Pertama, para petobat baru yang menjadi murid merupakan bukti dari buah kerasulannya (ayat 1-3). Rasul Paulus memberikan argumentasi dasar yang tidak dapat disangkal, yaitu bahwa tugas kerasulannya bukanlah sekedar status dan hisapan jempol belaka, bukan sekedar memiliki gelar Rasul, namun dibuktikan melalui "hasil-hasil pencapaian" (achievement), yaitu banyaknya petobat baru yang menjadi pengikut Kristus. Untuk apa menjadi Rasul kalau tidak menghasilkan petobat-petobat baru? Mungkin inilah yang dipikirkan oleh Rasul Paulus ketika ia menuliskan bagian ini.

Kedua, Rasul Paulus telah melepaskan hak-haknya sebagai Rasul Yesus Kristus (hak yang disepakati bersama untuk diterima sebagai seorang Rasul Kristus, sama seperti Rasul yang lain), sekalipun ia dapat memakai hak itu, ia "memilih untuk melepaskannya" dan tidak mendapatkan apa-apa (ayat 4-18). Semua ini dilakukan untuk sebuah kepentingan yang lebih besar, yaitu :

Ketiga, Agar proses pemberitaan Injil tidak terhalang dan tidak mendapat rintangan (ayat 12),

Keempat, Karena pemberitaan Injil adalah sebuah tugas dan mandat dari Yesus Kristus yang dibebankan kepadanya (ayat 17),

Kelima, Matanya ditujukan kepada UPAH, yaitu : ia tidak menerima apapun dan tidak mendapatkan haknya dari pekerjaan itu (ayat 18).

Jadi, apabila seorang Rasul yang karena apa yang sudah dikerjakannya berhak memperoleh hak-haknya sebagai Rasul (salah satunya adalah hidup dari hasil pekerjaannya itu, ayat 13), bukankah terlebih lagi Rasul Paulus, yang dengan segala hak-hak yang dapat diperolehnya, ia justru melepaskan hak-hak tersebut. Bukankah ia seharusnya lebih dari seorang Rasul? Ia memberikan dan melakukan lebih dari yang dituntut dari seorang Rasul Kristus, berarti 
janganlah ragukan lagi legalitas kerasulannya. Perpektif seperti inilah yang dapat ditangkap dari bagian ini.

\section{Metode Misi}

Metode misi yang dilakukan Rasul Paulus dalam bagian ini merupakan sebuah ringkasan dan kesimpulan dari metode yang dilakukannya dalam menjangkau jiwa bagi Kristus. Melayani dan hidup di dalam berbagai komunitas untuk memberitakan Injil membuat Rasul Paulus memerlukan strategi yang tepat agar langkah-langkahnya berjalan dengan efektif. Dalam ayat 19-23 secara umum disebutkan pola "aku menjadikan diriku.... supaya aku dapat....". Artinya, dalam menjangkau berbagai macam komunitas dan kelompok masyarakat, Rasul Paulus menjadikan dirinya menjadi hamba bagi semua orang agar ia dapat memenangkan sebanyak mungkin orang (ayat 19). Pokok bahasan ini akan dikupas dengan mendalam di bagian selanjutnya.

Melihat cara yang dipakai oleh Rasul Paulus dalam menjangkau banyak orang kepada Kristus, ada 2 hal penting yang perlu digarisbawahi, yaitu :

Pertama, Memang pemberitaan Injil harus dilakukan seefektif mungkin, dan dipahami kata "efektif" dalam pengertian "dahsyat dampaknya”, maka para misionaris, penginjil, dan pengajar gereja perlu memberitakan dan menjelaskan kabar tentang Yesus Kristus dengan cara-cara yang bisa dipakai oleh Roh Allah untuk menghasilkan dampak yang dahsyat. Namun pemberitaan Injil tidak pernah efektif dalam pengertian bahwa hal itu akan menghasilkan kondisi dimana pertobatan terjadi. Para Misionaris, penginjil dan pengajar yang memahami salib sebagai sebuah makna yang tak tergantikan dan dasar kabar dari Inti berita Injil. Eckhard J Schnabel berpendapat bahwa pertobatan pada iman kepada Yesus, Juruselamat yang disalibkan, 
selalu merupakan mukjizat, peristiwa atau proses yang disebabkan oleh kuasa Roh yang efektif dan Allah Israel yang murah hati dan panjang sabar. ${ }^{4}$ Hal ini berarti bahwa, bukan metode, strategi atau berbagai macam cara aplikatif yang mmbuat sebuah misi penjangkauan jiwa berhasil dengan efektif, namun yang lebih penting dari itu adalah : adanya kuasa Allah yang bekerja dalam setiap proses misi melalui peran Roh Kudus dalam setiap langkah-langkah yang ditempuh.

Kedua, Perlunya menargetkan kelompok orang yang homogen. Dalam Kisah Para Rasul 9:1-23 sangat jelas dijabarkan bagaimana sangat perlu untuk berfokus pada satu komunitas tertentu yang memiliki kesamaan (homogenitas) baik dalam segi usia, suku, latar belakang budaya, pendidikan, atau apapun itu, sehingga kebutuhan dalam rangka melakukan pendekatan misi dapat lebih mendarat pada sasaran. Donald A Mc Gravan dengan tegas menulis bahwa salah satu metode yang disarankan sebagai sarana efektif untuk pekerjaan misi dan pendirian gereja adalah fokus yang konsisten pada "kelompok orang" atau "unit-unit yang homogen", yang dapat didefinisikan sebagai "bagian masyarakat yang semua anggotanya memiliki beberapa karateristik yang sama". 5

\section{Goal Misi}

Tujuan akhir perjuangan Rasul Paulus dalam memberitakan Injil adalah :

Pertama, untuk meminimalkan rintangan dalam pemberitaan Injil (ayat 12)

Kedua, untuk UPAH yang sebenarnya tidak akan ia terima saat itu (ayat 18). Kebebasannya untuk tidak terikat dengan siapapun, yang menjadikan fleksibilitasnya menjadi

\footnotetext{
${ }^{4}$ Eckhard J Schnabel, Rasul Paulus Sang Misionaris: Pengalaman, Strategi dan MetodeMisi Rasul Paulus, (Yogyakarta: Andi Offset), 2010, hal.455.

${ }^{5}$ Donald A Mc Gravan, Understanding Church Growth, edisi III, Previsi dan editor CP. Wagner, (Grand RaRapids: Eerdsman), 1990, hal. 69.
} 
tinggi dalam pemberitaan Injil. Meminimalkan gesekan yang sekiranya dapat menjadi penghalang. Upah yang diterima bisa menjadi ikatan antara hak dan kewajiban menurut ukuran manusia secara normatif. Dengan tidak menerima Upah, Rasul Paulus menjadikan dirinya memiliki independensi yang tinggi dalam menunaikan misinya.

Ketiga, Mendapatkan bagian dalam Injil (ayat 23). Semua perjuangan, jerih lelah dan pengorbanannya diarahkan kepada Injil, agar ia mendapat bagian di dalamnya. Perhatiannya diarahkan kepada Upah kekal, dimana ia akan memperoleh bagian dalam apa yang sudah dijanjikan oleh Allah kelak.

\section{Tujuan Surat, Goal Yang Akan Dicapai}

Pokok ini erat kaitannya dengan pandangan Paulus mengenai kedudukannya sebagai seorang rasul. Dalam Injil, Yesus memilih para rasul untuk ambil bagian dalam misiNya, namun Paulus yang bukan merupakan murid Yesus pada waktu itu, berkali-kali menekankan dalam suratnya bahwa kerasulannya tidak kurang dari kerasulan para rasul di Yerusalem, khususnya dalam Surat Galatia.

Ia merasa berhak pula atas jabatan kerasulan itu. Dalam 1 Korintus 9:1 ia berkata bahwa Paulus menghubungkan tuntutan kerasulannya dengan kegiatan misi yang istimewa di tengahtengah orang Korintus, dan karena itu menganggap adanya hubungan khusus dengan mereka. Dia menyebut mereka "materai dari kerasulanku" (ayat 2) dan dengan serta merta mengemukakan hak-haknya atas mereka ... Otoritas yang mendasarkan panggilannya sebagai "rasul untuk bangsa-bangsa bukan Yahudi" (Roma 11:13), yaitu raas khususnya memberitakan Injil pada orang-orang bukan Yahudi. ${ }^{6}$

\footnotetext{
${ }^{6}$ Donald Guthrie, Teologi Perjanjian Baru 3, (Jakarta: BPK Gunung Mulia), 1993, hal 336-337.
} 


\section{Prinsip Utama}

Pendekatan yang dipakai oleh Rasul Paulus kepada 4 (empat) golongan orang berdasarkan 1 Korintus $9: 1-23$ adalah :

\section{Pertama, "Aku menjadi seperti..."}

Dalam pendekatan kepada kelompok orang tertentu, Rasul Paulus menjadikan dirinya seperti kelompok orang yang akan dia jangkau (ayat 20, 21, 22). "Bagi semua orang, aku telah menjadi segala-galanya...” Rasul Paulus mengidentifikasikan dirinya menjadi seperti kelompok orang target melalui : memahami sudut pandang berpikir mereka, hidup bersama-sama mereka, melakukan kebiasaan-kebiasaan mereka (sepanjang tidak bertentangan dengan Injil). Ia bersedia menjadi seperti siapapun asalkan ia dapat menjangkau lebih banyak orang bagi Kristus.

\footnotetext{
"Supaya aku memenangkan..."
}

Mengambil sikap "menjadi seperti...” dilakukan untuk sebuah tujuan utama, yaitu : “ supaya aku memenangkan orang-orang tersebut bagi Kristus" (ayat 19, 20, 21) dan goalnya adalah: "supaya aku mendapat bagian dalamnya (Injil)". Rasul Paulus memberikan hidupnya sendiri, waktu, tenaga, perhatian, perasaan (kasih), uangnya, secara total untuk sebuah tujuan yang jelas, yaitu agar sebanyak mungkin dimenangkan bagi Kristus (tujuan eksternal) dan supaya ia mendapat bagian dalam Injil (tujuan internal).

4 (empat) golongan orang yang dijangkau untuk menjadi target misinya melalui 2 (dua) prinsip diatas adalah : 


\section{Orang Yahudi}

Sebagai contoh, ia mau menjadi seperti orang Yahudi maupun mereka yang hidup di bawah Hukum Taurat supaya ia bisa memenangkan mereka (9:20).

KPR 18:18

“. . . sesudah ia mencukur rambutnya di Kengkrea, karena ia telah bernazar"

Bagian dalam Kisah Para Rasul 18:18 ini ditulis ketika Rasul Paulus sedang berada di Korintus, dalam perjalanan menuju Antiokhia pada pertengahan musim gugur sekitar tahun 52$55 \mathrm{M}^{7}$

Mencukur (keirw keiro), dilafalkan : ki'-ro, berasal dari kata dasar (primary verb), yang dalam bahasa Yunani berarti keiramenov, keirasyai, keirasyw, keirontov ; yang dalam bahasa Indonesia terjemahan bebas berarti mencukur rambutnya, emnggunting rambutnya, raambutnya digunting, yang menggunting bulunya (shear, sheearer) : menggunting bulu (domba), mencukur rambut. Dalam bahasa Inggris berarti to seer (a sheep), to get or to be shorn, of hearing or cutting short the hair of head.

KPR 21:20-26

“... Sebab itu lakukanlah apa yang kami katakan ini : Diantara kami ada empat orang yang bernazar. Bawalah mereka bersama-sama dengan engkau, lakukanlah pentahiran dirimu bersama-sama dengan mereka dan tanggunglah biaya mereka, sehingga mereka dapat mencukurkan rambutnya ; maka semua orang akan tahu,

\footnotetext{
${ }^{7}$ Bruce, F. F. 1986 Paul the Apostle. Pp. 696-720 in The International Standard Bible Encyclopedia, vol. 3, edited by Geoffrey W. Bromiley. (Grand Rapids: William B. Eerdmans Publishing Company), Hal. 709.
} 
bahwa segala kabar yang mereka dengar tentang engkau sama sekali tidak benar, melainkan bahwa engkau tetap memelihara hukum Taurat".

Penjelasan a dan b :

Di Kengkrea, yang sangat dekat dengan Korintus, pelabuhan di mana orang-orang yang melaut dari Korintus naik kapal, Paulus atau Akwila (teks asli tidak memastikan yang mana) mencukur rambutnya, untuk melepaskan dirinya dari nazar seorang nazir. Sesudah ia mencukur rambutnya di Kengkrea, karena ia telah bernazar. Orang-orang yang tinggal di Yehuda yang bernazar harus mencukur rambutnya di Bait Allah, tetapi yang tinggal di daerah-daerah lain boleh melakukannya di tempat lain. Kepala seorang nazir harus dicukur jika nazarnya dilanggar, dan harus memulai kembali dari awal. Atau, apabila waktu kenazirannya genap (Bilangan 6:9, 13, 18) dan sepertinya inilah yang terjadi di sini. Sebagian orang menganggap Akwilalah yang mencukur rambutnya, karena dia adalah seorang Yahudi (Kisah Para Rasul 18:2), dan mungkin memelihara agama Yahudinya lebih dari biasanya.

Namun ada juga dugaan lain jika Pauluslah yang melakukannya, karena mengenai dia harus mengakui hal yang sama $(21: 24,26)$. Paulus bukan hanya menuruti orang-orang Yahudi untuk sementara waktu, menjadi seperti orang Yahudi (1Korintus 9:20) bagi mereka, supaya dia dapat memenangkan mereka. Dia juga melakukannya karena nazar orang nazir, walaupun sekadar upacara, dan yang seperti itu akan segera lenyap, masih memiliki nilai moral dan arti yang sangat saleh, dan karenanya pantas sebagai yang terakhir lenyap dari semua upacara agama Yahudi. Orang-Orangnnazir dikaitkan dengan nabi-nabi (Amsal 2:11), dan benar-benar merupakan kemuliaan Israel (Ratapan 4:7).

Oleh karena itu, tidak aneh jika Paulus mengikatkan dirinya untuk sementara waktu dengan nazar orang nazir, dengan tidak meminum anggur dan minuman yang memabukkan, dan 
tidak mencukur rambutnya, untuk membuat dirinya diterima oleh orang-orang Yahudi. Dan dari nazar inilah sekarang dia melepaskan diri.

\section{Orang Yang Tidak Hidup di Bawah Taurat}

Di ayat ini Paulus menyinggung tentang orang yang tidak hidup di bawah Hukum Taurat (ayat 21a). Dalam teks Yunani dipakai sebutan anomos $(\mathrm{a}=$ tidak; nomos = hukum). Kata ini dalam Alkitab seringkali memiliki arti negatif yang merujuk pada orang/tindakan yang anti atau melanggar hukum (Lukas. 22:37; Kisah Para Rasul 2:23; 2 Tesalonika 2:8; 1 Timotius 1:9; 2 Petrus 2:8). Apakah arti seperti ini yang dimaksud Paulus di 1 Korintus 9:19-23?

Perlu tampaknya memikirkan alternatif arti yang lain, karena arti di atas tidak sesuai dengan konteks 1 Korintus 9:19-23. Rasul Paulus sedang memikirkan anomos dalam arti "status", yaitu orang yang tidak memiliki Hukum Taurat = orang non Yahudi, bukan tindakan dari orang durhaka/pelanggar Hukum Taurat. Ada beberapa alasan yang kuat mengapa perlu sebaiknya memahami anomos di ayat ini bukan secara negatif.

Pertama, walaupun kata sifat anomos sering berarti negatif, tetapi kata keterangan anomōs pernah dipakai Rasul Paulus untuk orang-orang non Yahudi secara umum yang berdosa tanpa Hukum Taurat (Roma 2:12). Dari konteks yang ada,anomōs di sini berarti "orang yang tidak memiliki Taurat", bukan yang melanggar Taurat (bandingkan dengan pemahaman “berdosa tanpa Taurat", "dihakimi tanpa Taurat").

Kedua, paralelisme dengan kelompok "mereka yang hidup di bawah Hukum Taurat" (hypo nomon, 9:20b) mendorong kita menafsirkan anomos secara sejajar tetapi kebalikan dari hypo nomon. Karena hypo nomon lebih mengarah pada status sosial Yahudi, maka anomos juga kemungkinan besar dipahami dalam konteks status sosial non-Yahudi. 
Ketiga, jika anomos di pasal 9:21 merujuk pada pelanggar Hukum Taurat, maka Rasul Paulus tidak mungkin mengungkapkan "aku menjadi seperti orang yang tidak hidup di bawah Taurat". Ia tidak mungkin mengikuti dosa mereka, apalagi di ayat ini ia juga menambahkan "aku tidak hidup di luar hukum Allah tetapi di bawah Hukum Kristus”. Jadi, anomos di sini merupakan ungkapan lain untuk orang-orang non-Yahudi yang tidak hidup di bawah Taurat.

Ketika Rasul Paulus mengatakan bahwa ia hidup seperti anomos, ia tidak mungkin memaksudkan ini secara etnis, karena ia secara etnis tidak mungkin berubah dari orang Yahudi menjadi orang non-Yahudi. Ungkapan ini pasti merujuk pada kebiasaan hidup atau budaya non Yahudi. Secara khusus, Rasul Paulus sedang membicarakan tentang kebiasaan makan, karena memang isu di pasal 8-10 adalah tentang makanan. Di tengah komunitas non-Yahudi,Rasul Paulus mengikuti pola makan mereka. Ia tidak keberatan jika harus membeli bahan makanan di pasar yang pasti sudah dipersembahkan sebelumnya kepada para dewa (10:25-26). Ia tidak menghindari ajakan makan orang lain (10:27).

Tindakan ini membutuhkan keberanian yang besar dan pemahaman teologis yang kuat. Bagi orang Yahudi, makan bersama orang non-Yahudi merupakan sesuatu yang sangat sensitif, menimbulkan ketidaknyamanan dan agak mustahil untuk dilakukan (Kisah Para Rasul 10:11-15, 28; Galatia 2:11-14). Cara memasak maupun memakan orang non-Yahudi tidak mungkin memenuhi peraturan kosher (halal) versi Yahudi. Bagaimanapun, Rasul Paulus rela membangun relasi dengan orang non-Yahudi dengan resiko bahwa ia harus merasa tidak terbiasa dan berpotensi untuk disalahpahami orang Yahudi yang lain. Ia bisa saja dianggap sebagai pelanggar Taurat atau orang yang gaya hidupnya plin-plan sesuai pergaulan yang ada.

Rasul Paulus selanjutnya memberi tambahan bahwa ia tidak hidup di luar hukum Allah (ayat 21b). Dalam teks Yunani kita dengan mudah menemukan permainan kata di sini: Rasul 
Paulus menjadi seperti anomos, tetapi ia sendiri bukanlah anomos Allah. Ia memang mengadopsi kebiasaan orang non-Yahudi yang tidak memiliki Taurat, tetapi bukan berarti bahwa ia sendiri hidup tanpa aturan. Ia mau menjadi “without law” (tanpa hukum), tetapi ia bukan“lawless" (“pelanggar hukum”). Hal ini mengajarkan sesuatu yang sangat penting bahwa kebebasan Kristiani di dalam Kristus bukan berarti "antinomianisme” (sebuah paham yang menekankan kebebasan mutlak tanpa aturan sama sekali). Kita memang tidak hidup di bawah Taurat lagi, namun itu bukanlah izin untuk hidup secara sembarangan (Roma 6:14-15).

Bagi Rasul Paulus orang percaya tidak mungkin hidup tanpa hukum. Kita berada di bawah hukum Allah (7:19). Dengan demikian kita bisa mengatakan bahwa selalu ada batasan dalam kebebasan Kristiani. Dalam kaitan dengan isu seputar makanan, Rasul Paulus pun memiliki batasan yang jelas. Ia tidak mau makan bersama orang non-Yahudi di dalam kuil mereka, karena itu tergolong penyembahan berhala (10:6-22). Ketika ia menerima undangan makan orang lain dan tindakan itu menjadi batu sandungan, Rasul Paulus memilih untuk tidak meneruskan makan (10:28).

Penegasan Rasul Paulus bahwa ia tidak hidup di luar hukum Allah merupakan sesuatu yang perlu dilakukan. Rasul Paulus memikirkan dua tujuan di sini. Ia ingin menghindari kesalahpahaman atau fitnahan orang lain yang sering menuduh dia meniadakan tuntutan hukum (Kisah Para Rasul 21:21; Roma 3:8) untuk menyenangkan hati banyak orang (Galatia 1:10). Ia juga ingin menegur sebagian jemaat Korintus yang menganggap keselamatan di dalam Kristus sebagai alasan untuk hidup sembarangan (5:1-3; 6:13). Mereka secara sembarangan menggunakan kebebasan Kristiani sampai menjadi batu sandungan bagi orang lain (8:9).

“Hukum Allah” yang dimaksud Rasul Paulus sangat berkaitan dengan Kristus (ayat 21c). Hukum ini adalah hukum Kristus. Rasul Paulus jelas tidak sedang mengatakan bahwa Hukum 
Taurat bukanlah hukum dari Allah. Apa yang ingin disampaikan Rasul Paulus di sini adalah perspektif yang baru tentang Taurat. Orang Kristen tetap memiliki "Taurat", yaitu Taurat yang dituliskan Allah dalam hati kita sebagai tanda perjanjian yang baru, seperti yang dinubuatkan oleh para nabi (Yeremia 31:31-33). Hukum ini diletakkan di dalam diri kita melalui karya Roh Kudus (36:26-27). Dalam Roma 8:2 Paulus secara jelas mengajarkan : "For the law of the Spirit of life in Christ Jesus has set you free from the law of sin and of death”.

KPR 17:16-34

“Karena itu di rumah ibadat ia bertukar pikiran (dialegomai dialegomai)dengan orang-orang Yahudi dan dan orang-orang yang takut akan Allah, di pasar setiap hari dengan orang-orang yang dijumpainya di situ" (ayat 17)

Dialegomai dialegomai (pelafalan : dee-al-eg'-om-ahee), merupakan jeniskata kerja yang dalam Yunani diartikan : dialegetai, dialegomenon, dialegomenou, dialegomenov, dielecyhsan, dielegeto, dielexato. Dalam TB berarti : berbicara, bertengkar, berbicara dengan, ia bertukar pikiran, ia membicarakan, pemberitaannya, mempertengkarkan, sedang bertengkar. Dan dalam AV berarti : dispute, reason with, preach unto, preach, speak. Seringkali didefinisikan (aorist pasif dielcyhn) yang artinya berbicara; bertengkar, membicarakan, mempertengkarkan, bertukar pikiran, berbicara, memberitakan. Dalam terjemahan bahasa Inggris memiliki makna : to think different things with one's self, mingle thought with thought; to ponder, revolve in mind ; to converse, discourse with one, argue, discuss.

Salah satu cara yang dipakai Rasul Paulus dalam misinya menjangkau banyak orang bagi Kristus adalah : selalu mencari rumah ibadat (Yahudi : Sinagoge) terlebih dahulu. Sinagoge, sekalipun itu berada di Kekaisaran Romawi, namun tetap memiliki fungsi yang sama seperti di 
komunitas orang Yahudi lainnya. Di sinagoge orang berkumpul untuk berbagai tujuan, antara lain: (1) tempat beribadah agama Yahudi; (2) tempat diadakannya pengajaran agama Yahudi, baik kepada orang Yahudi maupun non Yahudi oleh guru-guru agama Yahudi; (3) tempat dimana orang Yahudi ataupun non Yahudi berkumpul untuk berinteraksi, berdiskusi dan bertanya jawab soal agama. Bahkan oleh komunitas yang lain, dengan aliran/ sekte yang beraneka ragam; (4) tempat dimana hal-hal yang dianggap baru dibicarakan dan didiskusikan secara terbuka.

Kepentingan Rasul Paulus sangat besar untuk berada di sinagoge dan terlibat dalam pembicaraan dan diskusi dengan banyak orang, karena dengan bertukar pikiran, bertanya jawab, Paulus mendapatkan kesempatan untuk memberitakan Injil Kristus. Tidak hanya itu, diskusi terbuka menolong Rasul Paulus untuk mengetahuiperspektif berbagai macam orang dari berbagai latar belakang, yang pada akhirnya menolong dia untuk mengetahui isi pikiran mereka, sudut pandang dan latar belakang berpikir mereka, dan pada akhirnya menyamakan erpektifnya dalam hal tertentu untuk mendapatkan dasar pijak yang tepat dalam memulai pemberitaan Injil.

Bermula dari ini, Rasul Paulus juga mencoba mengidentifikasikan kebutuhan berbagai macam kelompok masyarakat dan belajar hidup "seperti" mereka, melakukan kebiasaankebiasaan mereka (sepanjang itu tidak bertentangan dengan Injil Kerajaan Sorga), dan hidup di tengah-tengah mereka. Membaur dan hidup bersama. Dia mengidentifikasikan dirinya dengan identitas kelompok masyarakat tertentu, supaya lebih mudah baginya membuat jembatan bagi diterimanya Injil di berbagai komunitas yang dijangkaunya.

Pertama, "Adapun orang-orang Atena dan orang-orang asing yang tinggal di situ tidak mempunyai waktu untuk sesuatu selain untuk mengatakan atau mendengar segala sesuatu yang baru (kainov kainos)" (ayat 21). 
Kainov kainos dilafalkan kahee-nos' yang berasal dari kata of uncertain affinity. Merupakan kata sifat (adjective), yang dalam Bahasa Yunani berarti kaina, kainh, kainhn, kainhv, kainon, kainoteron, kainon, kainouv, kainouv, kainw yang artinya : baru, yang baru (new). Kainoteron berarti yang terbaru (Kisah para rasul 17:21), tidak terpakai, tidak diketahui. Dalam terjemahan Bahasa Inggris berarti new, as respect from, recenly made, fresh, unused, unworn, as respect substance, of all new kind, unprecedented, novel, uncommon, unheard of.

Kali ini yang dihadapi Rasul Paulus adalah komunitas orang Yunani dan orang-orang asing, yang berarti mereka bukanlah termasuk kelompok orang Yahudi maupun kelompok orang yang berpegang kepada Hukum Taurat. Kelompok ini memiliki kebiasaan untuk berkumpul dan membicarakan sesuatu yang baru. Yang benar-benar sebuah berita atau informasi yang belum pernah didengar sebelumnya. Berita baru menjadi sebuah issue yang cukup menarik untuk dibahas dan dibicarakan bersama dalam komunitas ini berhubung beberapa sebab, yaitu : (1) tidak pernah didengar sebelumnya. Sungguh-sungguh "the real new", sesuatu yang mengusik rasa ingin tahu mereka ; (2) banyaknya aliran/sekte/ aliran agama dan gerakan yang ada pada permulaan abad setelah Kekristenan lahir, membuat orang Yunani (yang sesunguuhnya beraliran Helenisme) dan orang - orang asing lainnya ingin membandingkan nilai-nilai yang terkandung dalam ajaran baru dengan pemahaman mereka sebelumnya tentang Filsafat. Orang Yunani kebanyakan adalah pemikir-pemikir ulung karena dibesarkan dalam budaya dan ajaran Filsafat yang kuno dan dianggap paling unggul di dunia.

Rasul Paulus datang dan mempelajari kebiasaan dan pola berpikir mereka.Ia masuk dalam perspektif oarang-orang Yunani dan membaur dengan sekumpulan orang yang berada di situ untuk membicarakan hal-hal yang baru. Rasul Paulus menjadi seperti mereka, termasuk belajar untuk dapat terlibat dalam rasa ingin tahu kelompok ini. Selanjutnya, tindakan inilah 
yang menolong dia untuk menemukan dasar pijak yang sama dalam memberitakan Injil Kristus bada bagian selanjutnya.

Kedua, “. . . aku lihat, bahwa dalam segala hal kamu sangat beribadah kepada dewa-dewa. Sebab ketika aku berjalan-jalan di kotamu dan melihat barang-barang pujaanmu, aku menjumpai juga sebuah mezbah dengan tulisan : Kepada Allah yang tidak dikenal (agnoew agnoeo). Apa yang kamu sembah tanpa mengenalnya, itulah yang kuberitakan kepada kamu. ..." (ayat 22-23)

Agnoew agnoeo dilafalkan ag-no-eh'-o. Sebagai sebuah ungkapan negative particle dan termasuk verb. Dalam bahasa Yunani: agnoei, agnoein, agnoeitai, agnoeite, agnohsantev, agnooumen, agnooumenoi, agnooumenov, agnoountev, agnoousin, agnown, hgnooun. Arti dalam bahasa Indonesia: mengetahui, tahu, tanpa mengenalnya, kita tahu, kamu tidak tahu, Mereka tidak mengerti, ia tidak mengindahkannya, janganlah mengindahkan, tanpa pengetahuan, tetap tidak dikenal, tidak mereka ketahui, tidak tahukah kamu, yang jahil, tidak mengetahui, tidak mengerti, tidak mengakui, tidak mengenal, yang tidak dikenal.Dalam terjemahan Bahasa Inggris: be ignorant, ignorant, know not, understand not, ignorantly, unknown; yang didefinisikan : tidak tahu, tidak kenal, tidak peduli, tidak mengerti. To be ignorant, not to know, not to understand, unknown, to err or sin through mistake, to be wrong (as a negative particle) and not to know (through lack ofinformation or intelligence); by implication, to ignore (throughdisinclination):-(be) ignorant(-ly), not know, not understand, unknown.

Dalam Bahasa Yunani: agnoei, agnoein, agnoeitai, agnoeite, agnohsantev, agnooumen, agnooumenoi, agnooumenov, agnoountev, agnoousin, agnown, hgnooun. Dalam Bahasa Indonesia sehari-hari artinya : mengetahui, tahu, tanpa mengenalnya, kita tahu, kamu tidak tahu, Mereka tidak mengerti, ia tidak mengindahkannya, janganlah mengindahkan, tanpa pengetahuan, 
tetap tidak dikenal, tidak mereka ketahui, tidak tahukah kamu, yang jahil, tidak mengetahui, tidak mengerti, tidak mengakui, tidak mengenal, yang tidak dikenal.

Be ignorant, ignorant, know not, understand not, ignorantly, unknown. Artinya : tidak tahu, tidak kenal.

Menyambung bagian di atas pada point sebelumnya, atas dasar tindakan“menjadi sama dan berlaku seperti" orang Yunani dan orang-orang asing lainnya, Paulus berhasil menemukan dasar pijak yang sama dengan pola pikir mereka mengenai sosok allah yang selama ini diakui "keberadaannya" namun tidak pernah mereka kenal seperti apa eksistensi dan kiprah-kiprahnya. Kepada allah yang tidak dikenal inilah Rasul Paulus memulai pemberitaannya tentang Injil Kerajaan Surga. Menemukan dasar pijak yang sama, yaitu : ada pribadi yang dipuja dalam ibadah kepada dewa (allah), adanya mezbah untuk persembahan dan ibadah, dan sosok pribadi allah yang tidak dikenal, menjadi modal awal Paulus untuk membangun jembatan komunikasi dalam pemberitaan Injil.

Ketika Rasul Paulus memakai metode ini, sesungguhnya, sebelumnya, ia sudah berhasil "mencangkokkan" sudut berpikirnya pada perspektif berpikir oran Yunan dan orang-orang asing dari aliran agama yang lain pada saat itu. Ia juga sudah berhasil menjadi bagian dalam kelompok komunitas itu dengan duduk bersama dan bertanya jawab mengenai ibadah dan allah yang sejati. Walaupun hasilnya "terlihat" tidak begitu fenomenal berhubung penolakan dari berbagai orang, namun ada kelompok orang tertentu yang menerima berita Injil dan bertobat. Jelaslah bahwa, ada hasil yang positif dari pendekatan Rasul Paulus dalam menjangkau jiwa, ketika ia berusaha menjadi sama seperti kelompok orang yang dituju (menjadi target), yaitu menemukan kebutuhan komunitas secara spesifik dan mencari dasar pijak yang sama untuk membangun hubungan dan komunikasi. 


\section{Orang yang hidup di bawah Taurat}

KPR 16:13

“. . . kami menyusur sungai dan menemukan tempat sembahyang Yahudi, yang sudah kami duga ada di situ ; setelah duduk, kami berbicarakepada perempuanperempuan yang ada berkumpul di situ"

Lalew laleo, dilafalkan :lal-eh'-oa, prolonged form of an otherwise obsolete verb, dan merupakan jenis kata kerja (verb). Dalam Bahasa Yunani : elalei, elalhsa, elalhsamen, elalhsan, elalhsate, elalhsen, elalhyh, elaloumen, elaloun, lalei, lalein, laleisyai, laleite, laleitw, laleitwsan, laleiv, lalei, lalh, lalhsai, lalhsantev, lalhsav, lalhsei, lalhsh, lalhshte, lalhsomen, lalhsousin

Dalam Bahasa Indonesia sehari-hari diterjemahkan : berkata-kata, berbicara, berkata, Kukatakan, memberitakan, yang berkata-kata, yang dikatakan, untuk berbicara, diucapkan, mengatakan, mengucapkan, Aku berbicara, mengajar, telah Kukatakan, katakan, kami berbicara, Aku mengatakan, Ia berbicara, telah berbicara, berkatalah, aku berkata-kata, kami berkata-kata, ia berbicara, untuk memberitakan, yang berbicara, disampaikan, dikatakannya, Engkau berkatakata, yang telah dikatakan, kami berkata, ia berkata-kata, ia berkata, mereka memberitakan, beritakanlah, dikatakan, Aku berkata-kata, telah dikatakan, yang berfirman, diberitakan, aku mengatakannya, yang diucapkan, aku katakan, aku dapat berkata-kata, dapatlah berkata-kata, yang kauajarkan, dapat berbicara, yang dikatakan-Nya ketika, bercakap-cakap, aku berkata, yang harus kamu katakan, berkata-katalah, berseru, aku menyampaikan, berfirman, akan dikatakannya, Berkatalah, Beritakanlah, Dia yang berkata, Engkau mau bicara, Engkau percakapkan, Aku sampaikan, Aku menyampaikannya, Dalam Bahasa Inggris berarti : speak, say, tell, talk, preach, utter, misc. Yang diartikan : berbicara, berkata-kata; mengatakan, 
berbicara, berkata, mengucapkan, menyatakan, membisikkan, memberitakan. To utter a voice or emit a sound, to speak, to use the tongue or the faculty of speech, to utter articulate sounds, to talk, to utter, tellto use words in order to declare one's mind and disclose one's thoughts, to speak.

Ternyata menemukan tempat ibadah (sembahyang) Yahudi menjadi sebuah tindakan yang strategis dalam pemberitaan Injil bagi rasul Paulus, Hal ini dapat dimengerti karena beberapa alasan, yaitu : (1) sudah menjadi kelaziman dan kebiasaan yang berlaku umum bahwa tempat ibadah Yahudi adalah sebuah tempat yang dipakai untuk menjadi forum ibadah dan bertanya jawab, mengajar, memberitakan, bertukar pikiran, berdiskusi, menyampaikan pendapat dan ide-ide mengenai agama Yahudi. Namun sebenarnya, pada prakteknya, tempat itu tidak hanya dipakai oleh orang beragama Yahudi saja, namun juga orang dari kelompok aliran/sekte lain yang ingin tahu, membanding-bandingkan, mencari informasi sebanyak-banyak mengenai Taurah dan Hukum agama Yahudi, dan tidak menutup kemungkinan mengenai aliran/sekte lain yang sedang berkembang pada masa itu. Pun di Kekaisaran Romawi, di kota Roma, pemerintah Romawi juga menyediakan sarana tempat ibadah bagi orang Yahudi dengan fungsi yang sama seperti yang sudah dijabarkan sebelumya. Setiap orang boleh masuk dan ambil bagian dalam diskusi yang berlangsung di tempat itu, baik hanya sebagai pendengar atau pengajar. Jadi sangat masuk akal apabila Rasul Paulus memakai fasilitas ini sebagai sarana dan forum yang cukup strategis dalam membuka hubungan untuk membangun jembatan komunikasi tentang berita Injil kepada banyak orang, dari berbagai kelompok masyarakat ; (2) Wanita- wanita yang berkumpul di tempat itu adalah wanita-wanita yang memiliki status sosial tinggi dan terandang, karena tidak mudah bagi wanita biasa tanpa status sosial yang rendah dapat bergabung dalam forum diskusi di Sinagoga. Hanya wanita istri pejabat, atau pedagang kaya raya, atau berpendidikan tinggi yang 
dapat bergabung dengan kelompok ini. Rasul Paulus melihat bahwa kelompok wanita ini merupakan agen yang sangat potensial untuk berita Injil. Mereka memiliki pergaulan yang luas, dengan berbagai kalangan, terutama kalangan Kekaisaran dan orang-orang terpandang karena kekayaan dan tingkat pendidikannya. Wanita dalam kelompok ini adalah wanita yang moderat dan berpikiran maju, dapat dengan mudah menerima sesuatu yang baru, termasuk nilai -nilai tentang Injil dan Yesus Kristus. Pengaruh wanita dalam keluarga, kepada suami dan anak-anak juga menjadi sakah satu titik kekuatan wanita dalam pemberitaan Injil. Ditambah lagi dengan Injil dan ajaran Yesus Kristus yang menjungjung tinggi harkat dan martabat kaum wanita, menjadi titik kekuatan mengapa banyak kaum wanita bertobat dan menjadi Kristen.

Kebutuhan akan 2 prinsip di atas ditangkap dengan jelas dan baik oleh Rasul Paulus, Ia bertindak dan memposisikan dirinya pada kepentingan golongan target. Mengetahui bagaimana sistim yang berlaku dalam sebuah tananan masyarakat, dan mengambil tindakan yang mendukung dan tidak bertentangan dengan prinsip-prinsip kehidupan bermasyarakat pada masa itu. Menjangkau orang-orang kunci (wanita kunci) untuk menjadi Kristen dan menjangkau lebih banyak kelompok orang.

Galatia 2:3-15

“... tetapi ketika aku lihat kelakukan mereka tidak sesuai dengan kebenaran Injil, aku berkata kepada Kefas dihadapan mereka semua : “jika engkau seorang Yahudi hidup secara kafir dan bukan secara Yahudi, bagaimana engkau dapat memaksa saudara-saudara yang tidak bersunat untuk hidup secara Yahudi? (ioudaizw Ioudaizo)" 
Ioudaizw Ioudaizo dilafalkan ee-oo-dah-id'-zo, merupakan jenis kata v (verb) Yang dalam Bahasa Yunani berarti : ioudaizein, dalam bahasa Indonesia berarti : untuk hidup secara Yahudi. Dalam AV diartikan to live as do the Jews, yang berarti : hidup secara Yahudi, menurut adat Yahudi. Dalam dalam bahasa Inggris secara bebas berarti : to adopt Jewish customs and rites, imitate the Jews, Judaise, one who observes the ritual law of the Jews.

Bagian firman Tuhan ini merupakan sebuah issue yang sangat populer dalam prinsip penjangkauan jiwa (misi). Ada 5 (lima) hal prinsip yang dapat ditarik dari peristiwa tersebut, yaitu : (1) Kefas sebagai seorang Yahudi, harus konsiten dengan ajaran yang sudah dia berikan kepada orang lain (murid/pengikut). Konsistensi ini dituntut lebih seperti sebuah Integritas pribadi kepada Allah. Konsisten dengan ajarannya tidak sebatas pada apa yang dapat dilihat dan dinilai orang manusia (orang-orang di sekitarnya), namun lebih dari itu, Integritas yang dikerjakan secara konsisten karena itu merupakan tanggungjawab pribadi kepada Allah. Hal ini bukan tentang orang lain melihat atau tidak, namun tentang komitmen dan tekad yang kuat untuk hidup lurus dihadapan Allah. Lurus dalam arti : apa yang dikatakan (diajarkan) sama dengan apa yang dilakukan, dilihat atau tidak dilihat orang lain ; (2) Kebenaran Injil, harus menempati prioritas utama yang memiliki kedaulatan penuh dalam setiap tindakan dan prilaku Kefas (semua orang Kristen pada umumnya, dan para pemberita Injil secara khusus). Pelanggaran akan prinsipprinsip Alkitab merupakan celah yang dapat menjadi penghalang bagi pemberitaan Injil ; (3) Konsistensi Kefas dengan ajaran (isi berita Injil), tidak hanya berhubungan dengan relasi seorang hamba Tuhan dengan Tuhan, namun lebih dari itu, hal itu dibutuhkan oleh orang-orang yang yang sudah dimenangkan bagi Tuhan. Konsisten dengan ajaran. Ada relevansi yang positif antara berita yang disampaikan dengan bagaimana seorang hamba Tuhan menjalani kehidupannya. Orang Kristen, hamba Tuhan, sesungguhnya adalah kitab yang terbuka dan dapat dibaca oleh 
orang lain. Jangan hal itu menjadikan suatu penghambat dalam pemberitaan Injil ; (4) Secara khusus, dalam nats di atas, Rasul Paulus meminta supaya Kefas memikirkan Implikasi dari setiap tindakannya terhadap penerimaan orang terhadap berita Injil, sampai pada pilihan-pilihan yang praktis; (5) Bagaimana Kefas dapat memenangkan orang untuk mengikuti ajaran Yahudi, apabila ia sendiri hidup bertentangan dengan hal itu? Secara luas : bagaimana hamba Tuhan dapat menjangkau orang lain bagi Kristus, apabila kesehariannya tidak sesuai dengan ajaran Injil? Artinya : hamba Tuhan, para misi, setiap orang Kristen harus hidup sama seperti tuntutan Injil bagi orang Kristen, agar dapat memenangkan sebanyak mungkin orang bagi Kristus.

KPR 15:5-21

"Sebab aku berpendapat, bahwa kita tidak boleh menimbulkan kesulitan (parenoclew parenochleo) bagi mereka dari bangsa-bangsa lain yang berbalik kepada Allah,. ..." (ayat 19)

Parenoclew parenochleo, dilafalkan : $\quad$ par-en-okh-leh'-o yang merupakan jenis kata : v (verb) yang dalam Bahasa Yunani berarti : parenoclein, yang artinya menimbulkan kesulitan. Dalam terjemahan Bahasa Inggris berarti : trouble., yang artinya : mempersulit, menambahkan kesulitan. To cause trouble in a matter, to trouble, annoy, to harass further, annoy:-trouble.

Bagian ini menjabarkan pokok perselisihan antara Rasul Paulus dengan para orang Farisi yang sudah menerima Yesus. Petobat baru Farisi berpendapat bahwa, sekalipun seseorang non Yahudi sudah percaya Yesus, mereka tetap harus disunat sebagai tanda bahwa mereka menuruti Hukum Musa. Namun hal ini dibantah oleh Rasul Paulus, Petrus dan Barnabas. Alasan yang 
dikemukakan Rasul Paulus adalah: (1) Roh Kudus diberikan kepada semua orang yang percaya Yesus tanpa terkecuali di ayat 8; (2) Allah tidak mengadakan pembedaan sama sekali, setelah hati seseorang disucikan oleh iman di ayat 9; (3) Itu adalah bagian dari sikap mencobai Allah di ayat 10, karena beban itu mustahil dapat dipikul oleh para murid, bahkan oleh Para Rasul sendiri; (4) Keselamatan diperolah semata-mata oleh kasih karunia Allah di ayat 11; (5) Kehendak Allah adalah agar semua bangsa mengenal Dia dan diselamatkan di ayat $12-18$.

Maka dapat disimpulkan bahwa, melakukan Hukum Musa (Kitab Taurat), bukanlah syarat keselamatan. Keselamatan hanya diperoleh oleh karena kasih karunia Allah setelah pengakuan iman kepada Yesus Kristus. Melakukan ketentuan Hukum Taurat seteah pengakuan iman tidak akan menambah atau mengurangi keselamatan, dan tidak akan membawa pengaruh terhadap hal itu. Bahkan akan menjadi kesia-siaan bilamana itu bertentangan dengan Injil kasih karunia. Wajar apabila rasul Paulus menegaskan bahwa, tidak perlu dan iba pada orang non Yahudi yang percaya harus melakukan sunat agar diselamatkan. Hal ini tidak saja tidak berguna, namun juga MENYESATKAN. Keluar dari kaidah syarat keselamatan itu sendiri. Menjadi pengikut Kristus tidak berarti orang non Yahudi harus melakukan ketentuan Taurat, karena apabila dilakukan, itu berarti sangat mustahil untuk dijalani mengingat betapa mengikatnya Taurat dalam kehidupan manusia. Selain itu, tidak perlu ada faktor USAHA MANUSIA untuk memperoleh keselamatan. Karena keselamatan hanya didapatkan melalui iman kepada Yesus Kristus, yang oleh kasih karuniaNya membebaskan manusia dari tuntutan Hukum.

Prinsip "aku mau menjadi seperti..., agar semakin banyak orang yang dijangkau kepada Yesus Kristus ..., tidak berarti menggantikan kasih karunia Allah dengan aturan-aturan yang dibuat oleh manusia. Dalam konteks kehidupan berbudaya, beradat istiadat dan bermasyarakat, kebenaran Firman Tuhan HARUS memiliki otoritas paling tinggi untuk ditaati, melebihi segala 
tuntutan normatif masyarakat, apalagi bila nilai-nilai tradisi tersebut bertolakbelakang dengan dasar kebenaran Injil.

Semua tuntutan Taurat sudah digenapi di dalam Kristus melalui ketaatan-Nya yang sempurna (Roma 8:3-4). Ia memang datang untuk menggenapi Taurat, bukan meniadakannya (Matius 5:17-19). Di dalam Kristus Taurat telah diberi makna baru. Bagi orang Kristen Taurat bukanlah sebuah legalisme ataupun kumpulan persyaratan untuk keselamatan. Keagamaan legalistik seperti ini, terutama versi Farisi, pasti akan menimbulkan rasa letih lesu dan menjadi beban yang sangat berat bagi mereka yang hidup di bawahnya (Matius 11:28), karena itu Yesus menawarkan sesuatu yang lain. Kekristenan tetap memiliki beban dan kuk tersendiri, namun kuk ini enak dan bebannya pun ringan, karena kekristenan merupakan proses belajar dari Tuhan Yesus (Matius 11:29-30).

Hidup Kristus merupakan "Taurat" bagi kita. Inilah yang dimaksud dengan hukum Kristus. Sama seperti Kristus telah menunjukkan kasih kepada orang lain, demikian pula ketika kita melakukan hal yang sama kita telah memenuhi hukum Kristus (Galatia 6:2). Sama seperti Kristus telah rela menghambakan diri bagi orang lain (Markus 10:43-45), demikian pula Paulus mau mengikuti hukum Kristus ini dengan jalan menjadi hamba bagi semua orang (1 Korintus 9:19, 22b). Pendeknya, apa yang dinasehatkan Rasul Paulus di 1 Korintus 8-10 dapat dirangkum dalam satu kalimat "jadilah pengikutku sama seperti aku telah menjadi pengikut Kristus” (11:1). Inilah hukum Kristus, Taurat yang sejati.

\section{Orang YangLemah}

Kelompok terakhir yang disinggung Rasul Paulus adalah orang yang lemah (asthenēs, ayat 22a). Sekilas kita mungkin berpikir bahwa Rasul Paulus sedang membicarakan tentang 
orang yang lemah secara hati nurani di 8:7-13. Dalam Roma 14:1-15:3 Rasul Paulus juga membahas tentang perdebatan seputar makanan dan ia menyinggung tentang orang yang lemah secara hati nurani. Kesan tersebut akan memudar apabila kita memperhatikan konteks yang lebih sempit di 9:19-23. Dalam konteks ini Rasul Paulus sedang membicarakan tentang orang-orang yang belum diselamatkan, sebagaimana tersirat dari frase "supaya aku memenangkan mereka..." yang muncul berkali-kali. Dari petunjuk ini kita dapat menyimpulkan bahwa orang yang lemah di 9:22a bukanlah orang Kristen, sedangkan orang yang lemah hati nuraninya di 8:11 adalah orang yang sudah percaya.

Alasan lain mengapa orang yang lemah di 9:22a tidak boleh dipahami sebagai lemah secara hati nurani adalah ketidakadaan kata "seperti" di ayat 22a yang sebelumnya kita dipakai sejak ayat 20. Dalam hal ini terjemahan LAI:TB “aku menjadi seperti orang yang lemah" tidak terlalu tepat (terjemahan ini mungkin dipengaruhi oleh KJV/NKJV “I became as weak"). Semua versi lain memilih "I became weak" (ASV/NASB/RSV/NRSV/NIV/ESV/NET). Jika terjemahan hurufiah ini diikuti maka kita dapat menarik kesimpulan bahwa Rasul Paulus benar-benar lemah. Ia tidak menambahkan "walaupun aku...*tidak lemah+" seperti yang ia pakai di dua ayat sebelumnya (9:20-21), karena ia memang benar-benar lemah. Seandainya lemah di 9:22a dipahami dalam hal hati nurani, maka Rasul Paulus pun memiliki kelemahan itu, padahal bukan itu yang terjadi. Jadi, lemah di sini pasti bukan secara hati nurani. Kelemahan di sini adalah kelemahan yang memang dimiliki oleh Paulus juga.

“Orang yang lemah” di 9:22a sebaiknya dilihat dari sisi sosial. Kita sudah membahas berkali-kali bahwa di mata jemaat Korintus Rasul Paulus tampak sangat lemah (4:10; 2Korintus 10:10; 11:21; 13:4, 9). Gaya berkhotbah Rasul Paulus terlihat lemah jika dibandingkan dengan para orator ulung waktu itu, baik dari sisi isi, penampilan pembicara, maupun cara penyampaian 
(2:1-5). Pekerjaan Rasul Paulus yang kasar sebagai pembuat tenda ikut menegaskan kelemahan Rasul Paulus (4:10-13). Semua ini dilakukan Rasul Paulus karena ia ingin memenangkan orang lain yang lemah.

Jemaat Korintus sendiri dahulu adalah orang-orang yang lemah menurut ukuran dunia (1:26-28). Setelah bersentuhan dengan hikmat duniawi mereka malah merasa diri kuat dan hebat (1:18, 22-23). Kesombongan inilah yang menjadi salah satu masalah utama dalam jemaat, sehingga Rasul Paulus berkali-kali perlu mengajarkan kepada mereka bahwa kekuatan sejati adalah kelemahan di dalam Kristus (2 Korintus 11:30; 12:5, 9-10; 13:9). Jika kita lemah, maka kita kuat (2 Korintus 12:10a). Sebaliknya, orang yang merasa teguh berdiri maka ia akan jatuh (1 Korintus 10:13). Sebuah paradoks yang indah!

Apa yang diajarkan dan dilakukan Rasul Paulus di sini bersumber dari ajaran Tuhan Yesus (1 Korintus 11:1). Kristus mau mengasihi orang yang lemah (Roma 5:6). Ia mau menjadi miskin untuk memperkaya orang lain (2Korintus 8:9). Ia disalibkan dalam kelemahan, tetapi dihidupkan dalam kuasa Allah (2Korintus 13:4). Begitu pula dengan Rasul Paulus. Ia belajar menjadi lemah menurut ukuran dunia demi injil yang ia beritakan (2 Korintus 6:8-10). Sukacita Rasul Paulus adalah ketika kelemahannya justru dipakai Tuhan untuk menguatkan orang lain (2 Korintus 13:9 "sebab kami bersukacita apabila kami lemah dan kamu kuat).

1 Korintus 8:8-9

"Makanan tidak membawa kita lebih dekat kepada Allah. Kita tidak rugi apa-apa , kalau kita tidak makan dan kita tidak untung apa-apa, kalau kita makan. Tetapi jagalah, supaya kekebasanmu ini jangan menjadi batu sandungan bagi mereka yang lemah (parenoclew parenochleo)". 
Kata: proskoph proskopedilafalkanpros-kop-ay' yang dalam terjemahan alkitab bahasa Ingris dituliskan : offence, yang mengandung makna : an occasion of stumbling, to do something which causes others to stumble, leads them into error or sin.

Perlu hendaknya dalam keputusan mengenai pilihan-pilihan bersikap dan berprilaku secara normatif dalam masyarakat memperhatikan hal-hal yang yang praktis juga, misalnya : banyak hal DAPAT DILAKUKAN, namun apakah semuanya BERGUNA? Banyak hal berguna yang dapat dikerjakan, namun apakah semuanya mendatangkan MANFAAT bagi ORANG LAIN? Atau apakah itu menjadi BERKAT atau justru menjadi BATU SANDUNGAN bagi mereka yang lemah? Hendaklah setiap orang Kristen, terutama dalam tujuannya menjangkau jiwa bagi Kristus, betul-betul selektif terhadap apa yang perlu dilakukan atau tidak, agar sedapat mungkin, apabila hal itu tidak dapat menjadi berkat bagi orang lain, setidak-tidaknya tidak menjadi batu sandungan bagi mereka yang lemah.

Penjelasan lebih lanjut mengenai: menjadi batu sandungan bagi orang yang lemah sudah dijelaskan pada bagian terdahulu di atas *.

\section{Kontekstualisasi Berdasarkan 1 Korintus 9 :1-2}

Mengacu kepada prinsip-prinsip yang dilakukan oleh Rasul Paulus dalam mengadakan pendekatan ke berbagai pihak untk menjangkau sebanyak mungkin orang bagi Kristus, penulis menemukan beberapa catatan penting yang perlu dipertimbangkan dalam berkontekstual di masa kini, yaitu : 
Penjangkauan yang melampaui Identitas Etnis (orang Yahudi dan Non Yahudi)

Paulus biasanya digambarkan sebagai rasul bagi orang Non Yahudi. ${ }^{8}$ Gambaran ini tentu saja benar karea Paulus berbicara tentang kasih karunia yang diberikan kepadanya oleh Allah, yaitu aku boleh menjadi pelayan Yesus Kristus bagi bangsa-bangsa bukan Yahudi dalam pelayanan pemberitaan Injil Allah (Roma 15:16 dan Kisah Para Rasul 9:1-23)... Bukti menunjukkan bahwa Paulus tidak menggunakan strategi misi yang berfokus kepada kelompok etnis tertentu. Ia berkonsentrasi memberitakan Injil kepada semua orang di kota manapun, tak peduli asal mula estnisnya. ${ }^{9}$

Jika Paulus dan misi Kristennya lainnya yang lebih awal, yang semuanya orang Yahudi tidak menaruh banyak perhatian pada perbedaan etnis diantara orang Yahudi, sepenuhnya tepat jika Lukas dan Paulus menggunakan istilah ethne (bangsa-bangsa lain) sebagai istilah tehnis untuk non Yahudi. ${ }^{10}$

Mungkin itulah sebabnya Lukas tidak menjelaskan perbedaan etnis dan budaya kota-kota seperti Antiokhia Pisidia, tempat ia bertemu dengan penduduk asli Frigia dan Pisidia, keturunan kolonis Seleukid, keturunan veteran Italia Agustus, orang Yunani dan Yahudi. ${ }^{11}$

\section{Penjangkauan yang melampaui batas-batas Kelas Sosial}

Paulus juga tahu bahwa ada orang yang kuat dan lemah, sejumlah kecil pembuat keputusan yang kaya dan berpengaruh, dan sejumlah besar serta mayoritas orang miskin yang

\footnotetext{
${ }^{8}$ Jurgen Becker, Paul: Apostel to the Gentiles (Louisville: Westmister, 1993) ; Daniel J.S, Paul as Apostle to the Gentiles : His Apostolic Self Awareness and it's influence on the Soteriological Argument inRomans (Carlistle, UK;Paternoster, 1997).

${ }^{9}$ Eckard J Schnabel, Rasul Paulus Sang Misionaris. Perjalanan, Strategi dan MetodeMisi Rasul Paulus, (Yogyakarta, Andi Offset), 2010, hal.240.

10 Jurgen Becker, Paul Outside of the Walls : A Study of Luke's Socio-Geographical Universalism in Acts 14:8-20, AnalectaBiblica 143 (Rome : EditricePontificio Instituto Biblico, 2000), hal.152-53.

${ }^{11}$ Robert L. Mowery, "Paul and Christanius at Pisidian Antioch", (Biblica87), 2006, hal. 221-42, 230-32, 241.
} 
biasanya "tidak bersuara". Ia tahu bahwa ada laki-laki dan perempuan, orang yang merdeka dan bebas, budak orang berpendidikan, seperti yang nyata dalam beberapa perikop ini : Galatia 3:28, 1 Korintus 1: 26-29, 1 Korintus $12: 13$, Roma 1:14-16, Kolose 3:11.

Dalam 1 Korintus 1:26-29, Paulus merujuk pada dua kelas utama dalam masyarakat Yunani - Romawi. Di satu sisi ada "orang bijaksana" (sophoi), yaitu warga negara yang berpendidikan, kaum intelektual. Mereka kurang lebih identik dengan "yang kuat" (dynatoi), yaitu orang yang berpengaruh, yang merupakan pembuat keputusan kota, anggota dewan kota dahulu atau sekarang dan keluarga mereka, orang yang kekayaannya seringkali menjadi basis status sosial mereka yang tinggi. Mereka adalah orang "yang mulia berdasarkan kelahiran" (eugeneis), anggota elite lokal yang mengontrol keputusan yang mempengaruhi kehidupan orang yang tinggal di kota itu. Pada sisi spektrum sosial lainnya, yang membentuk 95\% populasi kota pada abad ke-1, ada "orang bodoh" (mora), yaitu orang yang tidak memiliki hak untuk belajar, membaca dan menulis. Mereka kurang lebih identik dengan "kaum lemah" ( asthene), yaitu orang yang tidak memiliki kekuasaan politik atau ekonomi yang tidak mempunyai pengaruh . Mereka adalah orang yang "dihina" (exoutthenemena) oleh anggota aristrokat setempat, yang dipandang sebagai "hal yang bukan sebenarnya" (to me onta), sebagai orang-orang yang pada akhirnya tidak relevan. ${ }^{12}$

Orang yang bijaksana, kuat berdasarkan kelahiran adalah orang yang menduduki posisi curcus honorum, di jalur karier di kota dan provinsi Kekaisaran Romawi . Mayoritas penduduk yang tinggal di kota, terlebih-lebih yang ada di pedesaan, tidak berpendidikan, tidak berdaya, tidak memiliki pengaruh, berasal dari keluarga sederhana, orang yang oleh kaum elite dipandang bodoh , lemah, rendah, hina, dan sungguh-sungguh "bukan siapa-siapa"

\footnotetext{
${ }^{12}$ Johannes Munck, Paul and the Salvation of Mankind, (Atlanta, Knox: 1977), hal. 16.
} 


\section{Kesimpulan}

Beberapa nilai inti (core value) yang dapat diambil dari penggalian misiologi Rasul Paulus menurut 1 Korintus 9:1-23 antara lain adalah :

Pertama,Tugas pemberitaan Injil, yang secara praktis dalam keseharian dapat diistilahkan Bersaksi Bagi Kristus, bukan semata-mata tugas orang Kristen "yang terpanggil secara pribadi" saja (misalnya Evangelis, Misionaris, Pendeta), namun merupakan tugas setiap orang Kristen yang sudah diselamatkan. Tugas ini merupakan keharusan bagi setiap orang yang beriman kepada Yesus Kristus, agar dapat ambil bagian dalam Injil, seperti yang dituliskan oleh Rasul Paulus sebagai tujuan misinya. Tentu saja disesuaikan dengan kapasitas setiap orang.

Kedua,Perlu menetapkan sasaran penjangkauan jiwa pada orang atau komunitas tertentu. Hal ini untuk memudahkan dalam menentukan cara yang tepat dan membangun jembatan komunikasi berdasarkan dasar pijak yang sama dalam menciptakan relasi melalui komunikasi yang efektif.

Ketiga, Tidak ada penjangkauan jiwa yang berhasil dari usaha yang setengah-setengah. Diperlukan totalitas. Totalitas misi yang dilakukan Rasul Paulus menjadi sebuah model dalam membangun jembatan kepada pihak/ komunitas tertentu. Totalitasnya adalah dengan menyerahkan dirinya sendiri sepenuhnya untuk menjadi seperti karakteristik kaum yang dijangkau, agar sebanyak mingkin orang dapat mendengarkan Injil dan diselamatkan. Totalitas yang berarti mau melakukan apapun untuk lebih menganal dan masuk, diterima menjadi bagian kelompok yang menjadi target/ sasaran misi.

Metode apapun yang dipakai dalam penjangkauan jiwa, hal yang paling penting adalah : Karya dan Keterlibatan Allah melalui pekerjaan Roh Kudus diantara para pemberita Injil dan 
komunitas sasaran. Metode yang paling hebat dan reputasi yang sebaik apapun, tidak akan lebih penting dari keterlibatan kuasa Allah dalam proses penjangkauan jiwa tersebut. 


\section{BIBLIOGRAFI}

Bencker, Jurgen, Paul :Apostel to the Gentiles, Louisville : Westmister, 1993; Daniel J.S, Paul as Apostle to the Gentiles: His Apostolic Self Awareness and it's influence on the Soteriological Argument in Romans, Carlistle, UK;Paternoster, 1997.

Bercker, Jurgen, Paul Outside of the Walls : A Study of Luke's Socio-Geographical Universalism in Acts 14:8-20, AnalectaBiblica 143, Rome: EditricePontificio Instituto Biblico, 2000.

F, Bruce, F. 1986 Paul the Apostle. Pp. 696-720 in The International Standard Bible Encyclopedia, vol. 3, edited by Geoffrey W. Bromiley. Grand Rapids: William B. Eerdmans Publishing Company.

Gravan, Donald A Mc, Understanding Church Growth, edisi III, Previsi dan editor CP. Wagner, Grand RaRapids: Eerdsman, 1990.

Guthrie, Donald, TeologiPerjanjianBaru 3, Jakarta, BPK GunungMulia, 1993

Ladd, George Eldon, TeologiPerjanjianBaru 2, Kalam Hidup, Bandung, 1999.

Mowery, Robert L., "Paul and Christanius at Pisidian Antioch", Biblica87, 2006.

Munck, Johannes, Paul and the Salvation of Mankind, Atlanta, Knox : 1977.

Schnabel, Eckhard J, Rasul Paulus Sang Misionaris :Pengalaman, Strategi dan MetodeMisi Rasul Paulus, Andi Offset, Yogyakarta, 2010. 
132| Jurnal Teologi S A N T UM D O M I E 